\title{
Deconstructing Orientalist Discourse through Narrative Strategies in The Hundred
}

\section{Secret Senses}

\author{
Xiao-zhen Hou, Yu Ma \\ Gansu Normal University for Nationalities, Hezuo, Gansu Province 747000
}

\begin{abstract}
In the Orientalist discourse, the Orient was backward and silent and was deprived of right to have their voice heard. However, in The Hundred Secret Senses, the author Amy Tan, the famous contemporary Chinese American writer, deconstructed Orientalist discourse by using some narrative strategies: talk-story and double first-person limited point of view.
\end{abstract}

Key words: Amy Tan; The Hundred Secret Senses; talk-story; double first-person limited point of view; Orientalism

\section{Introduction}

The Hundred Secret Senses is another masterpiece by the famous Chinese-American writer Amy Tan after the publication of her first two novels The Joy Luck Club and The Kitchen God's Wife. The conflict and reconciliation between the half-sisters Olivia and Kwan reflect the confrontation and dialogue between Chinese and Western cultures. The novel attracted hundreds of thousands of readers after its publication in 1995 and remained on the New York Times best-seller list for Three months and was short-listed for the Orange Prize for Fiction in 1996.

Orientalism "studied, depicted, and reproduced" Oriental culture. (Mamdani, 2004: 32) In the Orientalist discourse, the Orient was backward and silent and was deprived of right to have their voice heard. Therefore, it is the primary goal for those outsiders to break silence and struggle for an equal opportunity to speak. As a Chinese American writer, Amy Tan is dedicated to endow her Chinese characters with right to speak in her literary works. In The Hundred Secret Senses, Tan deconstructed Orientliast discourse by using some narrative strategies: talk-story and double first-person limited point of view.

\section{Talk-story}

Talk-story, a unique novelistic form of storytelling, was created by contemporary Chinese-American writer Maxine Hong Kingston in her masterpiece The Woman Warrior and was developed and enriched by Amy Tan in her novels. "By the time Amy Tan published her first novel, Kingston had already introduced the general reading public to the talk-story narrative style." (Huntley, 1998: 31). Amy Tan is foremost a storyteller (http://theschoolmarm.com) Like Kingston, Tan uses oral stories to structure her novels as well as to develop her characters. The purpose of talk-story in Tan's novels is not simply for the Mothers to tell stories to their American-born daughters; it is, to a certain extent, the best way to rewrite and protest against the situation of "aphasia" and "silence" suffered by the Chinese immigrants to the United States.

Terms like "aphasia" and "silence" are no doubt one of the characteristics of the Chinese immigrants' numbness mentality under long-term suppression. In Amy Tan's novels, the Mothers who immigrated to the United States from China belong to those who were forgotten and marginalized in American mainstream society. They suffer from various forms of racial prejudice and discrimination. Their original ethnic identities and positive images were distorted by the Western mainstream discourse, patriarchal ideology and Oriental discourse.

In The Hundred Secret Senses, Kwan is thoroughly an Other in the American society. Before Kwan's arrival at America, Olivia's Caucasian 
mother imagined that "she'll probably be shy, so don't jump all over her...And she'll be skinny as a beanpole, so I don't want any of you to making fun of her..." (Tan, 2004: 9) And when she arrived, her appearance and behavior further exposed her Otherness in a White society.

This person looked like a strange old lady, short and chubby, not exactly the starving waif Mom pictured or the glamorous teenage sister I had in mind. She was dressed in drab gray pajamas, and her broad brown face was flanked by two thick braids...She dropped her bag, fluttered her arms, and bellowed, "Hall-oo! Hall-oo!" Still hooting and laughing, she jumped and squealed the way our new dog did whenever we let him out of the garage...(Ibid 9)

Here Kwan's very first attempt to assimilate into American society was misunderstood and then she was silenced by the American-born Olivia. In the eyes of the Whites, Chinese immigrants always keep silence and don't have the right and ability to speak for themselves. But if Chinese Americans always keep silence, they would never make their own voice heard and the misunderstanding between them and the American mainstream society couldn't be eliminated. Kwan told Olivia that she could see people in the world of Yin and communicate with those ghosts. This secret was let out by Olivia to her parents. As a result, Kwan was sent to the Mary's Help.

...When the doctors and nurses ask me questions, I treat them like American ghosts-I don't see them, don't hear them, don't speak to them. Soon they'll know they can't change me, why they must let me go...

Unfortunately, her Chinese silent treatment backfired. The doctors thought Kwan had gone catatonic. Things being what they were back in the early 1960s, the doctors diagnosed Kwan's Chinese ghosts as a serious mental disorder.
They gave her electro-shock treatments, once, she said, then twice, she cried, then over and over again. Even today it hurts my teeth to think about that. (Ibid 14)

Since silence couldn't be of any use for her in the American society, Kwan tries to break silence by talk-story which allows Chinese American writers to privilege the voices of their Chinese American characters. Just as Amy Ling argued, "breaking silence is a good way for Chinese women to subvert their stereotypes and to assert their identities." (Ling, 1990: 20)

The next time I saw her at the hospital, she again confided in me. "All that electricity loosened my tongue so I could no longer stay silent as a fish. I became a country duck, crying gwa-gwa-gwa!-bragging about the World of Yin...." (Tan, 2004: 14)

In the novel, the relationship between the half-sisters is actually a special mother-daughter one and Kwan actually plays the role of Mother. No matter when her sister was in trouble, Kwan always tried to help and comfort her by means of doing everything she can, including talk-story which is what she most good at. Different from the stories told by the mothers in her other novels; Kwan told absurd stories in this novel, intentionally blurring the boundary between the real world and the fictional world, which having traces of the magic realism. Her mysterious and absurd stories about her past life in her Chinese hometown in the period of Taiping Rebellion in the $19^{\text {th }}$ century makes the readers can't distinguish reality from dreams. As an Other who couldn't assimilate into the White society both culturally and ethnically, Kwan used talk-story as a weapon to avoid and protest against mainstream hegemony culture. As a result of her absurd stories, she has been sent to a psychiatric hospital for treatment. However, after coming from the hospital, she continues to tell her World of Yin. Unwilling to be transformed and assimilated by the American 
mainstream values and beliefs, Kwan keeps talking story to maintain her spiritual sustenance and cling to the Chinese culture.

To sum up, talk-story is a narrative strategy often used by Chinese-American writers and most of the ethnic minority writers. It helps to recover the fractured history and the forgotten memory; it helps to link the past and the present of characters to restore the repressed and split soul in the mainstream culture. In Tan's novels, the function of talk-story takes on two levels: first and to a lesser extent, the Chinese talk-story tradition finds its way into the written novel form; and second, talk-story is an important communicative tool between the mothers and daughters since, through the engagement in this interactive and dynamic activity, they both come to terms with their relationship and their own identities. According to Wendy Ho, talk-stories provide a means for the women characters to challenge and critique western feminist criticism, Orientalist representations of Chinese American women in American culture. (Ho, 1999: 112) In The Hundred Secret Senses, talk-story played an important role. Through Kwan's Yin stories, Olivia comes to understand her half- sister's selfishless love for her and her Orientalized prejudices toward Kwan was eliminated. Olivia realized that "in spite of all our obvious differences, Kwan thinks she and I are exactly alike. As she sees it, we're connected by a cosmic Chinese umbilical cord that's given us the same inborn traits, personal motives, fate, and luck." (Tan, 2004: 19) At the end of the novel, Olivia and her husband Simon reconciled in their marriage and their long-term problem of infertility was also resolved with the birth of a daughter. Every change in Olivia's life is due to Kwan's talk-story. And by using this strategy, Amy Tan endowed the marginalized Kwan the power to speak and deconstructed Orientalized prejudices toward the Chinese Americans.

\section{Double First-person Limited Point of View}

In addition to talk-story, double first-person limited point of view is another narrative strategy used by Amy Tan to deconstruct Orientalist discourse hegemony. Structurally, one of the most distinctive characteristics of the novels of Amy Tan is that it has two layers of narrative in which two narrators (most often Mother and daughter) narrate their history and reality respectively. In The Hundred Secret Senses, the narratives of the primary narrator Olivia and the secondary narrator Kwan are intertwined to develop the plot. Both Olivia and Kwan adopted the method of first-person limited point of view to narrate their stories in a retrospective way. Olivia tells what happened in her real life. Olivia was born in America with a Chinese father and a Caucasian mother. When his father was dying, he asked his wife to find his another daughter who was born in mainland China and take her to America to live with the family. From then on, her half-sister called Kwan came into her life and always told her absurd stories of ghosts. When her marriage with Simon was in serious trouble, Kwan managed to bring the couple to China with her. The journey to China improved the relationship between Olivia and Simon. However, Kwan entered a mysterious cave in order to find the lost Simon and never came out again. When the couple returned to America, Olivia gave birth to a daughter who adopted Kwan's name. On the contrary, Kwan, both the secondary narrator and the character in Olivia's narration, tells what she and Olivia experienced in her past life. When foreign missionaries spread their religion in Guilin, China in 1864, both Nunumu (Kwan in present life) and Miss Banner (Olivia in present life) worked for the missionaries and they developed enduring friendship. The war of the Taiping Rebellion broke the peace of their life. Having realized Miss Banner was in danger; Nunumu refused to flee alone and finally chose to end her life with her good friend.

The use of double first-person limited point of 
view in her novels provides the narrators with opportunity for an equal dialogue which in turn works to deconstruct the Western hegemonic discourse.

Dialogue as a text was already in existence in Plato's Socratic Dialogues. However, dialogue at that time is still on the surface of literary stylistics, just limited to the direct speeches within quotations which were actually monologues expressed by the mouth of others. The Russian literary critic Bakhtin developed it as a self-sufficient theory to a new level. Bakhtin defined dialogue as a way of human existence and their interdependence. "I" and "Other" are the basis for dialogue and the relationship between them are of equality. There are two important concepts in Bakhtin's dialogism: micro-dialogue and macro-dialogue. Micro dialogue is mainly involved in the dialogue between the protagonist and different voices, including his dialogue with his own self, others and the environment. Macro-dialogue is a potential structural dialogue between the various parts of the novel; it is not the dialogue between the characters; in other words, it is a kind of relationship. It has two layers of meaning: the first layer refers to the nature of dialogue between human life and human thought reflected in the works. In other words, it is a dialogic relationship between human thoughts in life. The clash of different social thoughts is often presented in the works in an oppositional way. The second layer refers to the dialogue between the author and the protagonist, which exists both in and out of text. Here, we will focus on the first layer of meaning of macro-dialogue reflected in The Hundred Secret Senses---the clash of Eastern and Western cultures.

Both the primary narrator Olivia and the secondary narrator Kwan tell their respective stories from the first-person limited point of view and their narration are intertwined in the development of the plot. Through the whole novel, some chapters are told by Olivia and some, by Kwan; and some chapters contains the narration of both narrators. Due to their significantly different background of growth and education, Kwan represented the traditional Chinese culture while Olivia represented the American popular culture. Therefore, when Tan have the two sisters tell their respective stories alternately, she actually presents the two cultures on the same platform, giving them equal opportunity to speak for themselves. As a result, the novel forms a macro-dialogue relationship in structure. The effect of the dialogue is to eliminate confrontation and realize the idealistic purpose of harmonization within differences. The confrontation, conflict and reconciliation between the two narrators are also the process of Chinese traditional culture and American popular culture coming from confrontation to dialogue.

\section{Conclusions}

The Hundred Secret Senses is Tan's third masterpiece which explores the relationship between two half-sisters Olivia and Kwan. The conflict and reconciliation between them symbolizes the clash and dialogue between Chinese and American culture. Because of the Chinese culture deeply rooted in her mind and her awareness of racial discriminations in the American mainstream society, Tan tries to deconstruct Orientalism in her works. In The Hundred Secret Senses, Tan's use of narrative strategies talk-story and double first-person limited point of view makes the marginalized voice heard.

\section{References}

\footnotetext{
[1]. Ho, Wendy. In Her Mother's House: the Politics of Asian American Mother- Daughter Writing. Walnut Creek: Altamira Press, 1999

[2]. Huntley, E. D. Amy Tan: A Critical Companion Greenwood Press, 1998

[3]. Ling, Amy. Between Worlds: Women Writers of Chinese Ancestry. New York: Pergamon Press, 1990

[4]. Mamdani, Mahmood. Good Muslim, Bad Muslim: America, the Cold War, and the Roots of Terrorism. New York: Pantheon, 2004

[5]. Tan, Amy. The Hundred Secret Senses London: Harper Perennial, 2004
} 